\title{
MODEL PELATIHAN TERPADU UNTUK MENINGKATKAN FUNGSI DAN PERAN SOSIAL ANAK DALAM MEMBINA KEMANDIRIAN
}

\begin{abstract}
Akmala Hadita*
Abstract

Some problems are often faced in educating children to be self-reliant. On the other hand independency is much required in their future life. This research conducted in RSPA Cisurupan, Garut, in April 2010 until April 2011, aimed at developing an integrated training model to improve function and social roles of the children in the independency. Employing research and development design with planning, preparation, implementation and maintaining, as well as evaluation, the model development involved the parents or the family members and the children. The research produced the Integrated Training Model to Improve the Function and Social Roles of the Children in Developing the Self-reliance, which had been validated in this research.
\end{abstract}

Keywords: integrated training, function, role, self-reliance

\begin{abstract}
Abstrak
Berbagai kesulitan sering ditemukan dalam membina kemandirian anak, padahal kemandirian itu sangat diperlukan dalam kehidupan anak di kemudian hari. Penelitian yang dilakukan di RSPA Cisurupan, Garut, pada April 2010 sampai April 2011 ini, bertujuan mengembangkan model pelatihan terpadu untuk meningkatkan fungsi dan peran sosial anak dalam kemandirian. Desain penelitian yang diterapkan ialah penelitian pengembangan (research and development) dengan tahapan perencanaan, persiapan, pelaksanaan pembinaan dan evaluasi hasil. Pengembangan model ini melibatkan orang tua atau anggota keluarga peserta pelatihan disamping peserta pelatihan itu sendiri. Hasil penelitian ini adalah berupa model pelatihan terpadu untuk meningkatkan fungsi dan peran sosial anak dalam membina kemandirian yang keberhasilannya telah teruji dalam penelitian ini.
\end{abstract}

Kata-kata kunci : pelatihan terpadu, fungsi, peran, kemandirian

\section{PENDAHULUAN}

Pendidikan merupakan salah satu lembaga yang melaksanakan "investasi manusia" yang dapat diandalkan sebagai pencetak kader-kader pembangunan yang mampu berdaya saing dalam menembus keterbatasan dan ketertinggalan antara negara terbelakang dengan negara maju. Oleh karena itu, pemerintah dalam menetapkan "tiga lembaga pendidikan”, yaitu pendidikan formal, nonformal, dan informal. Ketiganya merupakan upaya peningkatan kualitas sumber daya manusia.

Pelaksanaan pendidikan seumur hidup itu dilakukan di dalam lingkungan rumah tangga, sekolah dan masyarakat. Oleh karena itu, pendidikan merupakan tanggung jawab bersama antara keluarga, masyarakat, dan pemerintah. Kompleksnya permasalahan sosial

\footnotetext{
* Mahasiswa Program Doktor Pendidikan Luar Sekolah Universitas Pendidikan Indonesia
}

anak yang terus berkembang dewasa ini dilatarbelakangi oleh masalah sosial ekonomi, psikologi, dan pedagogi.

Selain itu, rendahnya tingkat pendidikan, pengetahuan, keterampilan, nilai, dan sikap yang dimiliki orang tua (keluarga) dan guru di sekolah dalam memahami berbagai permasalahan yang dimiliki atau disandang oleh anak juga menghambat pelaksanaan pendidikan seumur hidup. Masih terbatasnya kemampuan tersebut juga menyebabkan ketidakmampuan orang tua (keluarga) dan guru disekolah dalam mengatasi permasalahan dan kebutuhan anak sesuai dengan tugas perkembangannya.

Belum berkembangnya program pelatihan yang diselenggarakan untuk pembinaan anak pada saat ini dan relatif sedikitnya jumlah lembaga yang memberikan pelayanan bagi anak yang menyandang masalah sosial 
baik yang dilakukan oleh masyarakat maupun pemerintah menjadi hambatan tersendiri dalam upaya implementasi pendidikan seumur hidup, serta belum terbentuknya program pelatihan terpadu yang bersifat konsisten, terintegrasi, dan berkesinambungan antara pemerintah, keluarga, dan masyarakat serta sekolah dalam upaya peningkatan peran dan fungsi sosial anak dalam membina kemandirian.

Penelitian ini mencoba membuat model pelatihan terpadu untuk meningkatan peran dan fungsi sosial anak dalam membina kemandirian, serta menganalisis keterkaitan antara pengetahuan, nilai, sikap, dan keterampilan orang tua dan guru tentang pembinaan terhadap anak.

Selanjutnya, yang menjadi perhatian dari penelitian dan untuk memperjelas penelitian yang hendak dilakukan, serta agar permasalahan yang diteliti tidak terlalu luas dan disesuaikan dengan kemampuan yang dimiliki penulis, penulis merumuskan masalah yang akan diteliti sebagai berikut: bagaimana model pelatihan terpadu dalam upaya meningkatkan fungsi dan peran sosial anak dalam membina kemandirian?

Adapun tujuan dari penelitian ini yaitu 1) untuk memperoleh informasi mengenai model konseptual pelatihan terpadu dalam upaya meningkatkan fungsi dan peran sosial anak dalam membina kemandirian anak di RPSPA, 2) untuk memperoleh informasi mengenai model pelatihan terpadu dalam upaya meningkatkan fungsi dan peran sosial anak dalam membina kemandirian anak di RPSPA, 3) untuk memperoleh informasi mengenai efektivitas model pelatihan terpadu dalam upaya meningkatkan fungsi dan peran sosial anak dalam membina kemandirian anak di RPSPA, dan 4) untuk memperoleh informasi mengenai peran tenaga pelatih pada pelatihan terpadu dalam upaya meningkatkan fungsi dan peran sosial anak dalam membina kemandirian anak di RPSPA.

Untuk itu, langkah awal penulis adalah melakukan studi pendahuluan dengan cara melakukan studi lapangan dan studi pustaka tentang pembinaan anak yang berada di Rumah Perlindungan Sosial Petirahan Anak (RPSPA) Cisurupan Garut Jawa Barat.

\section{KAJIAN TEORETIS}

Sikula dalam Sumantri (2000: 2) mengartikan pelatihan sebagai proses pendidikan jangka pendek yang menggunakan cara dan prosedur yang sistematis dan terorganisir. Para peserta pelatihan akan mempelajari pengetahuan dan keterampilan yang sifatnya praktis untuk tujuan tertentu. Pendapat tersebut menunjukan bahwa pelatihan mementingkan adanya proses yang digunakan untuk memenuhi kebutuhan atau tujuannya.

Pendapat di atas menunjukan bahwa pelatihan merupakan proses kegiatan secara sadar untuk memperbaiki sumber daya manusia baik individu maupun kelompok dengan tujuan untuk meningkatkan aspek-aspek kemampuan intelektual, kepribadian mandiri, dan keterampilan khusus yang diharapkan untuk masa yang akan datang.

Selain itu, pelatihan terpadu sendiri adalah suatu proses kegiatan yang menciptakan kondisi dan stimulus melalui bimbingan, pembinaan dan/atau latihan untuk meningkatkan pengetahuan, keterampilan, nilai dan sikap dalam rangka meningkatkan fungsi dan peran sosial anak untuk mencapai kemandirian. Melalui pendekatan terpadu yang menghubungkan materi pembelajaran dengan aspek-aspek kehidupan sosial melalui keterlibatan peran serta pendidik, instruktur, dan keluarga secara sistematis, terorganisir, dan berkelanjutan.
Menurut Linton (1984: 148) fungsi sosial telah melekat dalam setiap individu karena merupakan suatu kebutuhan dasar. Fungsi sosial akan berjalan dengan baik dengan adanya pola-pola tingkah laku timbal balik antara individu-individu atau kelompok-kelompok individu. Posisi yang saling berhadapan di dalam pola tingkah timbal-balik semacam itu, secara teknik disebut "status". Selain itu, peran sosial merupakan segi dinamis daripada status, di dalam hidup kemasyarakatan, individu menerima suatu status dan mendudukinya di dalam hubungan dengan statusstatus lainnya. Apabila individu melaksanakan hak-hak dan kewajiban yang melekat pada status itu atau mewujudkannya, maka individu tersebut melakukan sebuah peran sosial. Peran dan status sosial tidak dapat dipisahkan, dan pembedaan antara kedua hal ini hanyalah merupakan "academic interest" saja. Tidak ada status sosial tanpa peran sosial, dan tidak ada peran sosial tanpa status sosial (Linton, 1984: 149).

Mandiri adalah keadaan dapat berdiri sendiri, tidak tergantung pada orang lain. Syaodih (1993: 4-5) mengemukakan bahwa manusia mandiri adalah manusia yang memiliki keunggulan dalam kemampuan, berkepribadian sehat dan bermoral kuat. Manusia unggul adalah manusia yang memiliki kemampuan tertentu, yang dapat dimanfaatkan dalam kehidupannya, baik dalam kehidupan pribadi, sosial maupun dalam 
karir atau pekerjaan. Keunggulan tidak berarti harus unggul dalam segala hal, dan mengungguli semua orang, tetapi unggul (excellent) dalam satu bidang tertentu dan tingkat tertentu. Keahlian atau kemampuan profesional juga didukung oleh penguasaan pengeta- huan dalam sesuatu bidang, tetapi dalam kadar yang lebih luas dan mendalam. Penguasaan pengetahuan tidak terhenti pada tahap memory (remembering), tetapi berlanjut dengan tahap berpikir atau thingking (problem solving, reasoning, conceptual thingking).

\section{METODOLOGI PENELITIAN}

Penelitian ini menggunakan pendekatan kualitatif dan kuantitatif desain eksperimental, sebagai bagian dari metode utama dalam penelitian ini adalah penelitian dan pengembangan (Research and Developoment). Menurut Borg \& Gall (1979 : 782) Research and Developoment is a process used develop and validate educational products.

Instrumen penelitian dalam penelitian kualitatif dan kuantitatif ini adalah peneliti sendiri dan dibantu dengan instrumen daftar pertanyaan penelitian (kuesioner), dan pedoman observasi (pengamatan langsung), serta studi dokumentasi.

Penelitian dilakukan di RPSPA Cisurupan Kabupaten Garut pada bulan April 2010 sampai April 2011. Subjek penelitian dalam model pelatihan terpadu di RPSPA ini, yaitu seluruh peserta pelatihan anak SD yang berusia 10-12 tahun yang duduk dikelas 4, 5 atau 6 yang mengalami hambatan fungsi dan peran sosial dan kemandiriannya. Sasaran penyelenggaraan pelayanan RSPA berjumlah 80 orang yang memiliki kriteria prestasi belajar anak menurun, sikap dan tingkah laku yang dapat menghambat fungsi sosialnya.

Langkah awal yang dilakukan yaitu melalui studi pendahuluan dengan cara melakukan studi lapangan dan studi pustaka tentang pembinaan anak yang berada di Rumah Perlindungan Sosial Petirahan Anak (RPSPA) Cisurupan Garut Jawa Barat.

Pada tahap awal setelah mengumpulkan informasi, observasi lapangan maka penulis merumuskan dalam sebuah analisa dengan menggunakan metode SWOT pada RPSPA dengan hasil sebagai berikut.

Tabel 1. Analisis SWOT Program Pelatihan di RPSPA

\begin{tabular}{|c|c|c|c|c|}
\hline $\begin{array}{c}\text { Komponen } \\
\text { Pelatihan di RPSPA }\end{array}$ & Keunggulan & Kelemahan & Peluang & Tantangan \\
\hline $\begin{array}{l}\text { Kurikulum: } \\
\text { 1. Tujuan } \\
\text { 2. Materi } \\
\text { 3. Waktu } \\
\text { 4. Sumber belajar } \\
\text { 5. Peralatan } \\
\text { 6. Praktik Pelatihan }\end{array}$ & $\begin{array}{l}\text { 1. Rumusan tujuan terdefinisikan } \\
\text { dengan jelas } \\
\text { 2. Materi pelatihan diberikan oleh } \\
\text { pekerja sosial di RPSPA } \\
\text { 3. Waktu belajar telah dirancang } \\
\text { dan disusun } \\
\text { 4. Gedung dan sarana pelatihan } \\
\text { telah tersedia } \\
\text { 5. Praktik dan pembinaan } \\
\text { dilaksanakan secara bersama- } \\
\text { sama oleh guru dan pekerja } \\
\text { sosial dari RPSPA }\end{array}$ & $\begin{array}{l}\text { 1. Aktivitas dan materi } \\
\text { pelatihan belum optimal } \\
\text { dalam mencapai tujuan dari } \\
\text { kurikulum pelatihan. } \\
\text { 2. Rancangan materi pelatihan } \\
\text { belum disusun secara } \\
\text { terpadu dengan melibatkan } \\
\text { faktor eksternal } \\
\text { 3. Belum adanya kerjasama } \\
\text { atau MoU dengan pihak luar } \\
\text { dalam pengembangan } \\
\text { kurikulum dan pelatihan } \\
\text { terpadu } \\
\text { 4. Penggunaan fasilitas yang } \\
\text { belum optimal } \\
\text { 5. Standar evaluasi bagi } \\
\text { proses dan praktik } \\
\text { pembinaan belum disusun } \\
\text { secara terpadu dengan } \\
\text { melibatkan faktor ekternal }\end{array}$ & $\begin{array}{l}\text { 1. Peserta memahami tujuan } \\
\text { pelatihan dalam waktu yang } \\
\text { cukup } \\
\text { 2. Bagi peserta dapat } \\
\text { menyimak dan menyerap } \\
\text { materi pelatihan dengan } \\
\text { antusias dan kreatif } \\
\text { 3. Bisa membuat dan mencari } \\
\text { kerjasama dengan pihak } \\
\text { luar sebagai sumber } \\
\text { peningkatan mutu dan } \\
\text { model pelatihan } \\
\text { 4. Memanfaatkan gedung dan } \\
\text { fasilitas secara optimal } \\
\text { 5. Penyusunan standar } \\
\text { evaluasi oleh pihak RPSPA }\end{array}$ & $\begin{array}{l}\text { 1. Menumbuhkan pemahaman } \\
\text { dan motivasi dalam proses } \\
\text { pelatihan di RPSPA kepada } \\
\text { semua peserta pelatihan } \\
\text { 2. Peserta harus disiplin dalam } \\
\text { melaksanakan proses } \\
\text { pelatihan } \\
\text { 3. Peserta pelatihan harus } \\
\text { dapat memanfaatkan waktu } \\
\text { dan kesempatan yang ada } \\
\text { 4. Memberikan pengetahuan } \\
\text { dan keahlian bagi semua } \\
\text { peserta } \\
\text { 5. Peserta pelatihan } \\
\text { diharuskan menggunakan } \\
\text { secara optimal semua } \\
\text { fasilitas yang ada di RPSPA }\end{array}$ \\
\hline Pekerja Sosial & $\begin{array}{l}\text { 1. Memiliki pengalaman dalam } \\
\text { pelatihan sosial dan anak } \\
\text { 2. Memiliki waktu dan } \\
\text { kesempatan yang besar } \\
\text { dalam proses pelatihan dan } \\
\text { pembinaan di RPSPA } \\
\text { 3. Komitmen dan disiplin dalam } \\
\text { proses pelatihan dan } \\
\text { pembinaan di RPSPA }\end{array}$ & $\begin{array}{l}\text { Terbatasnya pengetahuan } \\
\text { mengenai materi dan model } \\
\text { pelatihan juga system } \\
\text { pembelajaran yang terpadu } \\
\text { dan kreatif }\end{array}$ & $\begin{array}{l}\text { 1. Menambah pengetahuan } \\
\text { dan model pelatihan dan } \\
\text { pembelajaran dari berbagai } \\
\text { sumber dan kesempatan } \\
\text { 2. Mengikuti pelatihan } \\
\text { peningkatan tenaga } \\
\text { instruktur dan pekerja sosial } \\
\text { dari lembaga-lembaga } \\
\text { pendidikan } \\
\text { 3. Mengembangkan model } \\
\text { dan materi pelatihan lebih }\end{array}$ & $\begin{array}{l}\text { 1. Pekerja sosial harus mampu } \\
\text { meningkatkan skill dan } \\
\text { prestasi kerja di lingkungan } \\
\text { RPSPA } \\
\text { 2. Pekerja sosial harus } \\
\text { memiliki informasi, inovasi, } \\
\text { dan integrasi dalam } \\
\text { melakukan proses pelatihan } \\
\text { dan pembinaan di } \\
\text { lingkungan RPSPA }\end{array}$ \\
\hline
\end{tabular}




\begin{tabular}{|c|c|c|c|c|}
\hline $\begin{array}{c}\text { Komponen } \\
\text { Pelatihan di RPSPA }\end{array}$ & Keunggulan & Kelemahan & Peluang & Tantangan \\
\hline Siswa/Anak Terlantar & $\begin{array}{l}\text { 1. Memiliki latar belakang } \\
\text { pendidikan yang homogen } \\
\text { 2. Memiliki kesempatan untuk } \\
\text { melakukan pembinaan di } \\
\text { RPSPA } \\
\text { 3. Memiliki potensi untuk berubah } \\
\text { dan meningkatkan kualitas diri }\end{array}$ & $\begin{array}{l}\text { 1. Lingkungan keluarga } \\
\text { kurang mendukung proses } \\
\text { pembinaan dan pelatihan di } \\
\text { RPSPA } \\
\text { 2. Motivasi dan pemahaman } \\
\text { akan proses pembinaan } \\
\text { belum dipahami jelas oleh } \\
\text { peserta } \\
\text { 3. Adaptasi yang lambat } \\
\text { mempengaruhi proses } \\
\text { pembinaan di RPSPA } \\
\text { 4. Kompleksitas } \\
\text { permasalahan sosial yang } \\
\text { disandang anak } \\
\text { 5. Anak belum memiliki sikap } \\
\text { mandiri sehingga memiliki } \\
\text { hambatan peran dan fungsi } \\
\text { sosial yang mengakibatkan } \\
\text { memiliki hambatan dalam } \\
\text { belajar }\end{array}$ & $\begin{array}{l}\text { 1. Ada kesempatan } \\
\text { pembinaan dan bimbingan } \\
\text { 2. Adanya dukungan dari } \\
\text { pemerintah dan sekolah } \\
\text { 3. Tidak adanya biaya untuk } \\
\text { mengikuti pelatihan } \\
\text { 4. Bisa mengikuti pelatihan } \\
\text { dengan tetap mengikuti } \\
\text { pembelajaran formal } \\
\text { karena guru kelasnya hadir } \\
\text { dalam proses pembelajaran } \\
\text { di RPSPA }\end{array}$ & $\begin{array}{l}\text { 1. Peserta harus dapat } \\
\text { memanfaatkan waktu, } \\
\text { kesempatan, dan fasilitas } \\
\text { yang ada di RPSPA } \\
\text { 2. Peserta harus memupuk } \\
\text { motivasi dan disiplin dalam } \\
\text { pelatihan } \\
\text { 3. Peserta harus memiliki } \\
\text { kemauan untuk merubah } \\
\text { perilaku dan kebiasaan } \\
\text { buruk sebelum melakukan } \\
\text { pelatihan dan merubahnya } \\
\text { menjadi perilaku dan } \\
\text { kebiasaan baik } \\
\text { 4. Menyimak semua materi } \\
\text { dan keterampilan yang } \\
\text { diberikan. }\end{array}$ \\
\hline Guru Pendamping & $\begin{array}{l}\text { 1. Memiliki motivasi dan } \\
\text { integritas dalam proses } \\
\text { pelatihan } \\
\text { 2. Memiliki tugas formal dari } \\
\text { intitusi/sekolah mereka } \\
\text { 3. Memiliki komitmen dan } \\
\text { disiplin dalam } \\
\text { mengembangkan anak } \\
\text { didiknya }\end{array}$ & $\begin{array}{l}\text { 1. Terbatasnya pengetahuan } \\
\text { mengenai materi dan model } \\
\text { pelatihan juga system } \\
\text { pembelajaran yang terpadu } \\
\text { dan kreatif } \\
\text { 2. Guru pendamping kurang } \\
\text { memiliki pemahaman } \\
\text { mengenai pelatihan yang } \\
\text { dilaksanakan RPSPA } \\
\text { 3. Guru pendamping kurang } \\
\text { memahami permasalahan } \\
\text { sosial anak serta treatmen } \\
\text { yang akan diberikan pihak } \\
\text { RPSPA }\end{array}$ & $\begin{array}{l}\text { 1. Menambah pengetahuan } \\
\text { dan model pelatihan di } \\
\text { RPSPA } \\
\text { 2. Mengikuti pelatihan } \\
\text { peningkatan tenaga } \\
\text { instruktur dan pekerja } \\
\text { sosial dari lembaga- } \\
\text { lembaga pendidikan } \\
\text { 3. Sharing pengalaman dan } \\
\text { gagasan antara guru } \\
\text { pendamping }\end{array}$ & $\begin{array}{l}\text { 1. Guru pendamping harus } \\
\text { dapat meningkatkan skill } \\
\text { dan pengetahuan tentang } \\
\text { anak terlantar } \\
\text { 2. Guru pendamping harus } \\
\text { memiliki informasi, inovasi, } \\
\text { dan integrasi dalam } \\
\text { melakukan proses pelatihan } \\
\text { dan pembinaan di } \\
\text { lingkungan RPSPA }\end{array}$ \\
\hline Orang tua/Wali Siswa & $\begin{array}{l}\text { 1. Memiliki latar belakang } \\
\text { pendidikan dan ekonomi yang } \\
\text { heterogen } \\
\text { 2. Memberikan dukungan, } \\
\text { kesempatann bagi anak untuk } \\
\text { mengikuti pembinaan di } \\
\text { RPSPA } \\
\text { 3. Memiliki potensi untuk } \\
\text { berubah dan meningkatkan } \\
\text { kualitas pendidikan bagi anak }\end{array}$ & $\begin{array}{l}\text { 1. Pemahaman mengenai } \\
\text { tujuan dan proses } \\
\text { pembinaan di RPSPA } \\
\text { 2. Kurangnya pengetahuan } \\
\text { atau teknik mengenai } \\
\text { peningkatan kemandirian } \\
\text { anak }\end{array}$ & $\begin{array}{l}\text { 4. Menambah pengetahuan } \\
\text { dan model pelatihan di } \\
\text { RPSPA } \\
\text { 5. Mengikuti pelatihan } \\
\text { peningkatan orangtua } \\
\text { dibidang pembinaan anak } \\
\text { 6. Sharing pengalaman dan } \\
\text { gagasan antara orangtua }\end{array}$ & $\begin{array}{l}\text { 3. Orangtua harus dapat } \\
\text { meningkatkan skill dan } \\
\text { pengetahuan tentang anak } \\
\text { terlantar } \\
\text { 4. Orangtua harus memiliki } \\
\text { informasi, inovasi, dan } \\
\text { integrasi dalam pelatihan } \\
\text { dan pembinaan di } \\
\text { lingkungan RPSPA }\end{array}$ \\
\hline
\end{tabular}

Berdasarkan data tersebut, penulis menganggap perlu adanya suatu program pembinaan lanjut yang dilakukan oleh orang tua (keluarga) dan guru (sekolah) pascapelatihan, agar pembinaan yang telah diberikan efektif dan dapat dirasakan manfaatnya. Dengan demikian, perlu diungkap model penyelenggaraan dan proses pembinaan pada RPSPA saat ini. Perlu diformulasikan model pelatihan terpadu yang seperti apa pada RPSPA, yang dapat meningkatkan fungsi dan peran sosial dalam pembinaan kemandirian anak.

Perlu dikaji keefektifan, faktor pendukung, dan penghambat penerapan model pelatihan terpadu di RPSPA. Berdasarkan uraian diatas, peneliti menganggap perlu adanya sebuah pengembangan model pelatihan terpadu dalam upaya peningkatan fungsi dan peran sosial dalam pembinaan kemandirian anak yang dilaksanakan oleh RPSPA.

Merujuk kepada beberapa hasil kajian dan kasus, maka penulis merumuskan model hipotetik:

1. Kemandirian anak dan berfungsinya peran dan fungsi sosial anak sangat ditentukan oleh proses pembinaan orang tua/wali dan guru kelas di lingkungan tempat tinggalnya.

2. Kualitas pembinaan oleh orang tua/wali dan guru kelas terhadap anak sangat ditentukan oleh pengetahuan, skill, nilai, dan sikap orang tua/wali dan guru kelas.

Langkah awal dalam proses penelitian dan pengembangan tersebut, sebagaimana dikemukakan oleh Borg dan Gall (1979: 626) adalah sebagai berikut.

1. Penelitian pengumpulan informasi, meliputi review literatur, observasi lapangan dan persiapan laporan.

2. Perencanaan, meliputi penentuan model pelatihan yang cocok, penyusunan desain kurikulum dan pembelajaran, serta melakukan ujicoba dalam skala kecil.

3. Membuat rancangan model awal, meliputi pembuatan desain rancangan model pelatihan kemandirian anak dalam sistem pendidikan terpadu antara lembaga dengan orang tua.

4. Uji coba pendahuluan, dilakukan langsung di lokasi kegiatan pelatihan. Pada langkah ini dilakukan 
analisis data berdasarkan hasil wawancara, observasi, dan dokumentasi.

5. Revisi terhadap rancangan awal, dilakukan berdasarkan hasil yang ditemukan dalam studi ekspolatoris.

6. Uji coba produk utama, difokuskan pada variabel proses pelatihan, evaluasi, dan dampak kemandirian anak yang dilaksanakan di RPSPA.

7. Revisi terhadap produk utama, dilakukan berdasarkan hasil temuan dalam uji coba untuk siap diimplementasikan.

8. Uji coba operasional, dilakukan pada salah satu lembaga petirahan dengan melibatkan penyelenggara, pelatih dan anak-anak.

9. Revisi produk operasional, dilakukan berdasarkan hasil implementasi.

10.Diseminasi dan retribusi, dilakukan monitoring sebagai kontrol terhadap hasil akhir.

Uji untuk hipotesis dilakukan dengan uji korelasi, sementara untuk menguji efektivitas model pelatihan terpadu untuk meningkatkan fungsi dan peran sosial anak dalam membina kemandirian. Uji efektivitas dilakukan dengan cara uji beda dengan analisis data menggunakan pendekatan desain eksperimen dengan quasi experimental untuk metode yang digunakan adalah "Non-equivalent Control Group Design" dengan cara membandingkan rata-rata kesenjangan skor post test pada kelompok eksperimen dengan kelompok kontrol.

Bentuk perlakuan terhadap kelompok eksperimen adalah penerapan model pelatihan tepadu bagi orang tua/wali dan guru kelas serta pekerja sosial. Pelatihan tersebut mengakomodir materi-materi berupa:

1. Pemaparan program pembinaan anak di lingkungan RPSPA,

2. Pengertian tentang anak dan permasalahannya, kesejahteraan anak,

3. Peranan dan fungsi keluarga, motivasi bagi orang tua/ wali dan guru kelas dalam membina anak (teori perkembangan kemampuan belajar dan motivasi belajar anak),

4. Model dan trik pembinaan anak pasca pelatihan di RPSPA (konsultasi dan pengungkapan masalah, bimbingan pembentukan kepribadian anak).

\section{HASIL PENELITIAN}

Pelatihan terpadu dilaksanakan dalam rangka meningkatkan fungsi dan peran sosial. Fungsi dan peran sosial sendiri dapat dikatakan sebagai kemampuan seseorang dalam menjalankan peran sesuai dengan status yang disandangnya. Anak dapat dikatakan telah melakukan fungsi sosial dengan baik bila anak memiliki pola-pola tingkah laku yang baik dan wajar atau bisa dikatakan bertingkah laku sebagai seorang anak dalam hubungannya dengan orang lain di lingkungan sekitarnya. Sementara itu seorang anak dapat dikatakan telah menjalankan peran sosialnya bila anak tersebut telah melaksanakan dan mewujudkan hak-hak serta kewajiban yang melekat pada dirinya sebagai seorang yang memiliki status yang bernama anak. Peran dan status tidak dapat dipisahkan, tidak ada status tanpa adanya peran, dan tidak ada peran tanpa status.

Keterhambatan fungsi dan peran seorang anak dapat menjadi penghambat pula dalam membina kemandirian anak. Kemandirian anak dalam hal ini adalah suatu hal atau keadaan dapat berdiri sendiri tanpa bergantung kepada orang lain. Anak yang mandiri adalah anak yang mampu menjalankan tugas kehidupan sehari-harinya sesuai dengan tingkat dan tugas perkembangannya dengan penuh rasa kesadaran dan tanggung jawab baik terhadap diri sendiri, keluarga, dan lingkungan masyarakatnya.

Pelatihan terpadu dianggap sebagai suatu tahapan yang penting dalam memantapkan fungsi dan peran sosial dalam upaya membina kemandirian anak. Dalam penyelenggaraan pelatihan terpadu perlu adanya suatu rangkaian pembinaan yang dilakukan kepada orang tua (keluarga) dan guru (sekolah) pasca pelatihan, hal itu agar anak memiliki bekal wawasan, pengetahuan, skill, dalam hal permasalahan sosial anak serta bagaimana solusi atau pembinaan anak pasca mengikuti pelatihan terpadu. Demikian juga perlu diungkap model penyelenggaraan dan proses pembinaan pelatihan terpadu.

\section{Model konseptual "Model Pelatihan Terpadu Untuk Meningkatkan Fungsi Dan Peran Sosial Anak Dalam Membina Kemandirian"}

Melalui kajian empirik di lapangan diperoleh gambaran yang disajikan pada bagian ini berupa masih tingginya jumlah anak terlantar di Indonesia khususnya di pedesaan. Menurut data dari Biro Pusat Statistik dan Departemen Sosial RI pada tahun 2008 jumlah anak telantar berusia antara 6-18 tahun mencapai 2. 767.629 anak atau hampir $10 \%$ jumlah anak yang tersebar yang tinggal di perkotaan mencapai 492.281 anak dalam pedesaan mencapai 7.275.348 anak. Sedangkan yang tergolong rawan terhadap keterlantaran diperkirakan mencapai 10.322.768 anak, dengan rincian mereka yang tinggal diperkotaan mencapai 2.956.253 anak dan pedesaan sebanyak 7.326.421 anak. Hal ini 
menunjukan sebagian besar masalah keterlantaran anak diakibatkan oleh masalah ekonomi, sosial maupun psikologis. Dari data dan informasi tersebut dikaji indikator-indikator yang disajikan dalam bahasan ini, diantaranya data yang berkaitan dengan:

a. Profil RRPSPA Cisurupan Garut,

b. Peserta pelatihan,

c.Pelaksanaan kegiatan pembinaan di RRPSPA Cisurupan Garut,

d. Orang tua/wali atau keluarga dari anak peserta pelatihan di RRPSPA Cisurupan Garut.

Berhubungan dengan telaah penelitian terhadap pelaksanaan program pelatihan terpadu di RRPSPA Cisurupan Garut, akan dilihat dari tiga komponen, yang meliputi: telaah terhadap perencanaan komponen program, komponen pelaksanaan program, dan evaluasi kegiatan.

Dalam komponen perencanaan program, beberapa hal yang menjadi fokus utama dalam kajian ini adalah Jenis kegiatan yang dilakukan diantaranya, yaitu

a. Penjangkauan/koordinasi,

b. Sosialisasi Program,

c. Bimbingan dan motivasi sosial,

d. Seleksi,

e. Materi yang dipersiapkan,

f. Alokasi waktu yang ditetapkan,

g. Tenaga yang dipersiapkan,

h. Sasaran peserta, dan

i. Lokasi sasaran.

Dalam komponen pelaksanaan program, beberapa hal yang menjadi fokus utama dalam kajian ini adalah.

a. Jenis kegiatan pembinaan dan bimbingan sosial bagi anak.

b. Metode yang diberikan dalam penyampaian materi.

c. Media yang digunakan dalam proses pembinaan.

d. Waktu yang digunakan dalam proses pembinaan.

e. Tenaga pembimbing dan narasumber teknis.

f. Jenis dan tahapan proses pelaksanaan kegiatan pelayanan, pembinaan/bimbingan sosial yang meliputi;

1) Bimbingan sosial,

2) Bimbingan fisik dan kesehatan lingkungan,

3) Bimbingan belajar,

4) Bimbingan mental dan spiritual,

5) Bimbingan kepribadian,

6) Bimbingan bakat dan kreatifitas,

7) Konseling,

8) Pembahasan kasus

Selain itu penulis mengetahui hal-hal yang berkenaan dengan. a. Jenis dan materi yang digunakan,

b. Waktu kegiatan evaluasi,

c. Kriteria yang digunakan dalam melakukan evaluasi

d. Hasil penilaian guru, orang tua/wali atau keluarga.

Berdasarkan hasil di atas, maka model secara konseptual yang diujicobakan dapat dirumuskan dengan gambar sebagai berikut.

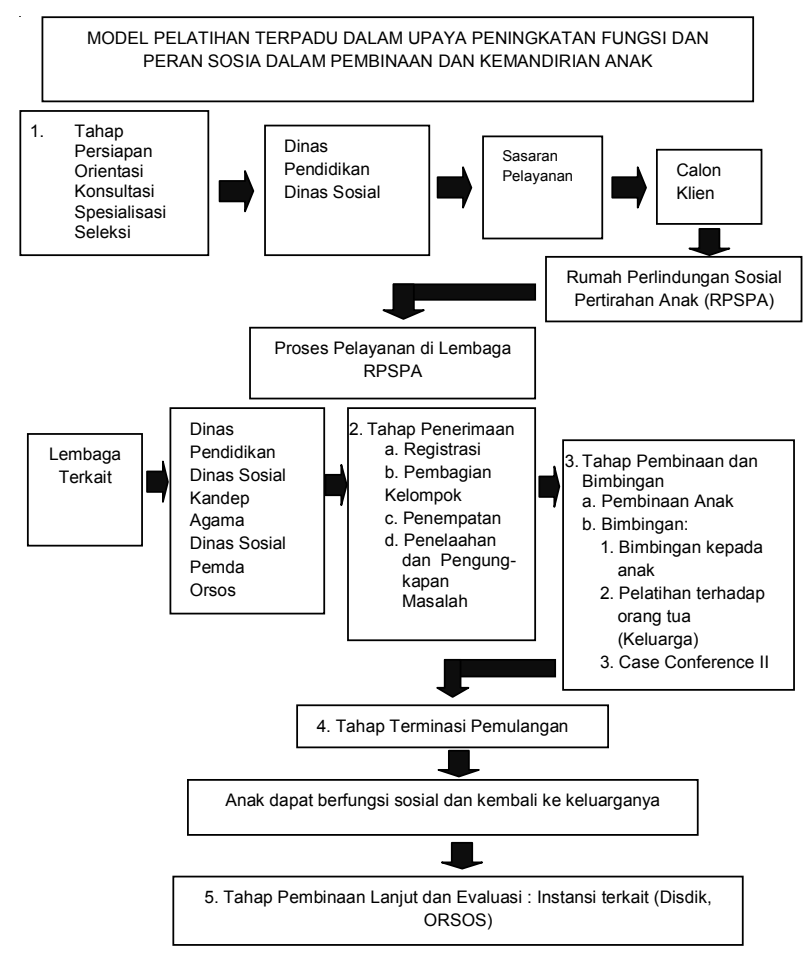

Gambar 1 Konseptual Model Pelatihan Terpadu

2. Model Implementasi “Model Pelatihan Terpadu Untuk Meningkatkan Fungsi Dan Peran Sosial Anak Dalam Membina Kemandirian"

Implementasi model pelatihan terpadu dalam upaya meningkatkan fungsi dan peran sosial anak dalam membina kemandirian dapat dibagi menjadi beberapa tahapan, yaitu persiapan, seleksi, pelaksanaan, evaluasi, dan pendampingan.

Dalam proses perencanaan dan persiapan meliputi penjangkauan atau kontak awal Dinas Sosial Kabupaten/Kota dan Dinas Pendidikan, sosialisasi pada Dinas Pendidikan yang menjadi sasaran pihak keluarga dan sekolah, seleksi dilakukan oleh guru kelas masingmasing sekolah bekerjasama dengan pekerja sosial dengan melakukan home visit dan penyuluhan dengan pihak keluarga calon peserta dan motivasi pada calon peserta dan keluarga.

Pada tahap pelaksanaan diawali penempatan anak di asrama dan selanjutnya dilakukan assesment dan diagnosa permasalahan pada anak kemudian mengadakan sidang kasus pertama dalam upaya 
rencana tindakan dan treatment yang akan diberikaan pada anak sesuai dengan permasalahannya. Selanjutnya pelaksanaan treatmen, pembinaan, dan bimbingan sosial pada anak sesuai dengan indikator permasalahan anak pembinaan yang diberikan dalam bentuk pembinaan fisik dan kesehatan, pembinaan keterampilan, bimbingan kepribadian, bimbingan keterampilan, bimbingan sosial, bimbingan belajar, bimbingan mental dan spiritual. Bimbingan sosial pada anak diberikan untuk mengatasi permasalahanpermasalahan yang dialami oleh anak, hal tersebut sesuai dengan pendapat Gunarsa (1986: 11), bahwa bimbingan sosial bertujuan untuk membantu anak dalam mengatasi kesulitan-kesulitan dalam kehidupan sosialnya sehingga anak mampu mengadakan hubungan-hubungan sosial dengan baik.

Tahap evaluasi dilakukan setelah pembinaan dan treatment diberikan untuk mengetahui sejauh mana perubahan sikap yang terjadi pada anak untuk dijadikan penilaian selanjutnya. Sidang kasus dua dilakukan untuk merancang pola pembinaan selanjutnya dengan mengacu pada hasil evaluasi, dan akan dijadikan rujukan dan rekomendasi pada pihak sekolah masingmasing dan keluarga.

Tahap berikutnya adalah mengadakan konseling dan pelatihan terpadu yang dilakukan terhadap orang tua/wali, keluarga dan guru asal sekolah guna menginformasikan prihal permasalahan pada anak serta pola pembinaan lanjut yang harus diberikan baik didalam lingkungan keluarga maupun lingkungan sekolah sesuai dengan rekomendasi tersebut di atas.

Tahap pembinaan lanjut dilakukan evaluasi secara bertahap setiap bulan dalam tiga bulan berturutturut setelah anak dipulangkan pasca mengikuti pelatihan di RPSPA, tujuannya untuk mengetahui sejauh mana perubahan sikap terjadi pada anak dan mengukur kemampuan orang tua atau keluarga dalam pembinaan lanjut dan pada akhirnya menciptakan komunikasi yang efektif antara pihak sekolah dengan keluarga.

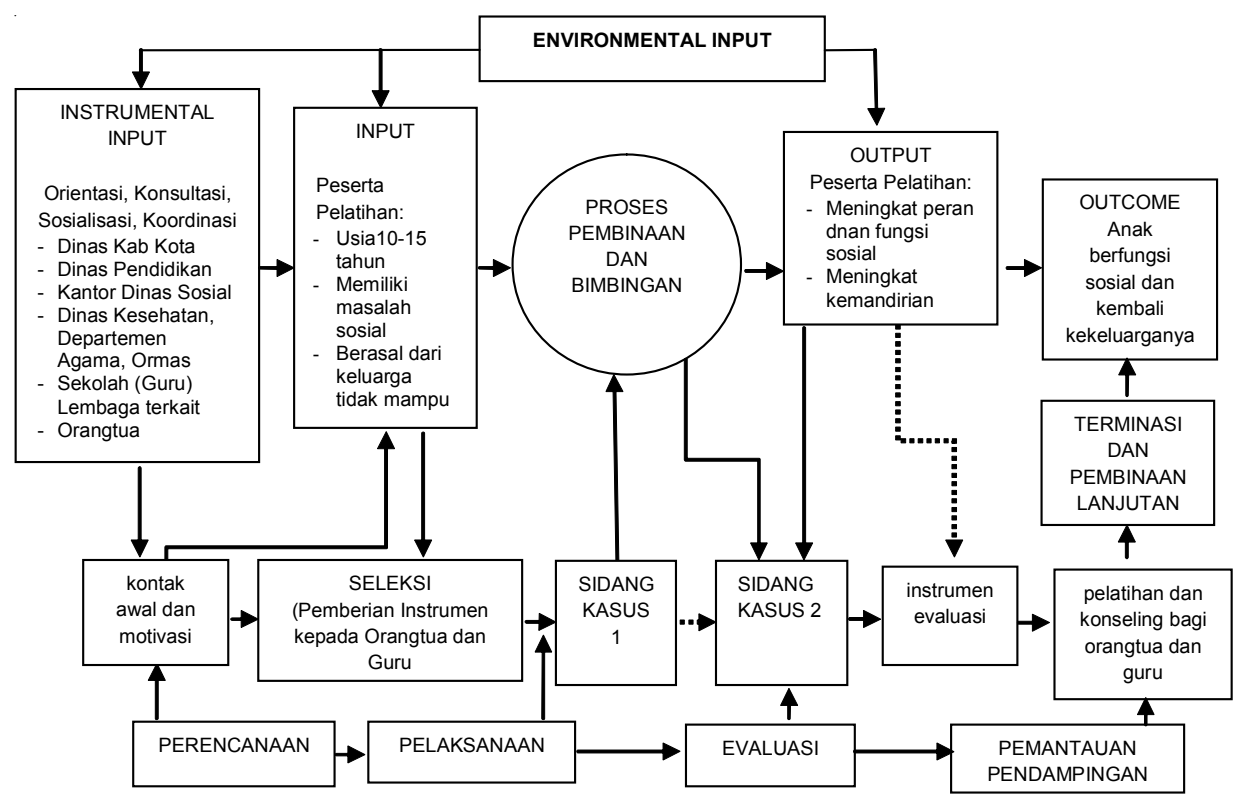

Gambar 2 Implementasi Model Pelatihan Terpadu

\section{Efektivitas Model Pelatihan Terpadu Untuk Meningkatkan Fungsi Dan Peran Sosial Anak dalam Membina Kemandirian}

Sebagaimana telah dijelaskan pada pendahuluan, bahwa tulisan ini bersumber dari penelitian penulis dengan menggunakan metode "Penelitian Pengembangan" (Research dan Development), menurut Borg \& Gall (1979 : 624), sedangkan uji untuk hipotesis dilakukan dengan uji korelasi, sementara untuk menguji efektivitas model pelatihan terpadu untuk meningkatkan fungsi dan peran sosial anak dalam membina kemandirian. Uji efektivitas dilakukan dengan cara uji beda dengan analisis data menggunakan pendekatan desain eksperimen dengan quasi experimental untuk metode yang digunakan adalah "Non-equivalent Control Group Design" dengan cara membandingkan rata-rata kesenjangan skor post test pada kelompok eksperimen dengan kelompok kontrol.

Dari hasil uji coba yang telah dilakukan dengan mengindahkan metodologi yang telah dirancang, diperoleh gambaran tentang efektivitas model Pelatihan terpadu untuk meningkatan peran dan fungsi sosial 
anak dalam membina kemandirian sebagaimana dijelaskan di atas adalah sebagai berikut:

a. Efektivitas model pelatihan terpadu untuk meningkatan peran dan fungsi sosial anak dalam membina kemandirian dapat diimplementasikan secara efektif dan efisien. Hal ini didasarkan pada adanya penguatan kemampuan orang tua/wali dan guru kelas dalam pengetahuan, nilai, sikap dan keterampilan dalam membina anak di lingkungannya pasca mengikuti pelatihan terpadu ini.

b. Selanjutnya, berdasarkan hasil evaluasi dengan menggunakan analisis komparasi hasil pre test dan post test dengan menggunakan uji beda, diperoleh data adanya peningkatan hasil yang signifikan dan terbukti pengaruh pengetahuan, nilai, sikap dan keterampilan orang tua/wali dan guru kelas dalam membina anak di lingkungannya, pasca mendapatkan pelatihan dari RPSPA, sangat besar sehingga pembinaan yang telah diberikan efektif dan dapat dirasakan manfaatnya.

4. Peran Tenaga Pelatih pada Pelatihan Terpadu Untuk Meningkatkan Fungsi Dan Peran Sosial Anak dalam Membina Kemandirian

Berhasil atau tidaknya pencetakan SDM atau keberhasilan peserta didik dalam menyerap ilmu pengetahuan tergantung pada profesionalisme dan dedikasi guru dalam tugasnya.

Dalam penyelenggaraan pelatihan terpadu sendiri tidak terlepas dari peran tenaga pendidik khususnya pelatih, tenaga pelatih pada pelatihan teknis sendiri yaitu pekerja sosial yang dibagi kepada dua kategori, yaitu tim pengarah dan tim pelaksana. Tim pengarah sendiri terdiri dari para ahli dari berbagai disiplin ilmu yang memberikan konsultasi khusus, yaitu social worker, dokter medis, pendidik, psikolog, intruktur keterampilan, ahli gizi, dan ahli lainnya yang relevan mendukung pelaksanaan kegiatan. Sedangkan yang menjadi tim pelaksana yaitu perangkat lembaga rumah perlindungan sosial petirahan anak, guru-guru pendamping, pekerja sosial fungsional, perawat kesehatan, guru agama, dan pengasuh (pembimbing).

Pekerja sosial adalah suatu bidang keahlian yang mempunyai tanggung jawab untuk memperbaiki dan mengembangkan interaksi sosial diantara orang-orang dengan lingkungan sosial sehingga orang itu tidak memiliki kemampuan untuk menyelesaikan tugas-tugas kehidupan mereka, mengatasi kesulitan-kesulitan serta mewujudkan aspirasi-aspirasi serta nilai-nilai mereka (Soetarso, 1980: 4)

Rasio petugas dengan anak yang tetirah di rumah perlindungan sosial petirahan anak adalah $1: 8-10$, dimana satu orang pelatih membimbing delapan sampai sepuluh anak.

Sebagaimana dikatakan dalam Undang-undang Sistem Pendidikan Nasional No.20 Tahun 2003 pasal 39 , bahwa tugas tenaga kependidikan adalah bertugas melaksanakan administrasi, pengelolaan, pengembangan, pengawasan, dan pelayanan teknis untuk menunjang berhasilnya proses pendidikan pada satuan pendidikan. Oleh karena itu dapat diungkapkan bahwa tenaga pelatih sebagai tenaga pendidik pada pelatihan terpadu memiliki tugas menjalankan administrasi pendidikan baik dalam pengelolaan, pengawasan maupun dalam hal-hal menjalankan pengawasan dan pelayanan teknis di institusi atau lembaga pendidikan. Tentu saja jalur pendidikan dimaksud baik formal maupun non formal.

Menurut Mathis dalam Irawati (2011), pelatih harus mempelajari dan menguasai beberapa hal dibawah ini.

a. Pengetahuan yang memadai dan mendalam dalam bidang keilmuan atau studi tertentu.

b. Kemampuan dalam bidang pendidikan dan keguruan (berkenaan dengan proses pembelajaran berupa teori, praktek dan pengalaman lapangan).

c. Kemampuan kemasyarakatan (kemampuan berinteraksi dalam kehidupan antara manusia dan masyarakat baik di lingkungan lembaga pelatihan maupun masyarakat luas).

d. Kemampuan kepribadian

Pada prinsipnya seorang pelatih bertanggung jawab atas penyampaian materi latihan serta hasil yang diperolehnya. Pelatih wajib melaporkan semua kegiatan latihan kepada Training Director, termasuk hasil penilaian atas peserta. Apabila dijabarkan, tugas utama seorang pelatih antara lain.

a. Mengajar secara teratur di kelas latihan.

b. Mengevaluasi hasil yang dicapai setiap peserta latihan dan melaporkannya kepada training director.

c. Memberikan catatan-catatan kepada peserta.

d. Menyiapkan bahan-bahan dan peralatan pelatihan.

e. Membantu manajer mengembangkan serta mengarahkan para peserta.

Menurut Moekijat (1990) peranan seorang pelatih/ trainer adalah sebagai pengajar, pemimpin kelas, pembimbing, fasilitator, peserta aktif, ekspeditor, perencana pembelajaran, pengawas, motivator, evaluator, konselor, dan penyidik sikap dan nilai. Pada pelatihan terpadu sendiri tenaga pelatih memiliki tugas sebagai pembimbing bagi anak dalam rangka meningkatkan fungsi dan peran sosial anak dalam membina kemandirian. 


\section{KESIMPULAN}

\section{Kesimpulan}

Dari hasil uraian di atas maka dapat diambil kesimpulan sebagai berikut:

Pertama, pelaksanaan pelatihan terpadu yang diselenggarakan di RPSPA Cisurupan Garut berkaitan dengan hal-hal proses pelaksanaan kegiatan pembinaan, evaluasi, dan pembinaan lanjut terhadap anak dan keluarga dan orang tua pasca mengikuti pelatihan di RPSPA. Model pelatihan terpadu di RPSPA mencakup beberapa tahapan yaitu: tahap perencanaan, persiapan, pelaksanaan pembinaan dan evaluasi hasil.

Kedua, implementasi model, terdiri atas persiapan, seleksi, pelaksanaan, evaluasi dan pendampingan, serta adanya proses home visit pada tahap persiapan dan evaluasi.

Ketiga, efektivitas model yang dikembangkan dikaji berdasarkan sejauhmana fungsi dan peran serta kemandirian anak setelah mengikuti pelatihan terpadu. Pelatihan terpadu berpengaruh secara signifikan terhadap fungsi dan peran sosial anak.

Keempat, tenaga pelatih sebagai tenaga pendidik pada pelatihan terpadu memiliki tugas menjalankan administrasi pendidikan baik dalam pengelolaan, pengawasan maupun dalam hal-hal menjalankan pengawasan dan pelayanan teknis di institusi atau lembaga pendidikan dalam rangka meningkatkan fungsi dan peran sosial anak dalam membina kemandirian.

Saran

Terdapat beberapa hal yang harus mendapat perhatian dalam pelatihan terpadu, sehingga penulis memberikan beberapa saran, diantaranya.

Pertama, tahap pembinaan lanjutan dan evaluasi menjadi sangat penting dalam menjaga konsistensi dan keberlanjutan pembinaan anak di lingkungan keluarga pasca pembinaan kemandirian di RPSPA.

Kedua, instrumen dan alat evaluasi harus mendapat perhatian dan dilaksanakan secara konsisten dan diperbaharui terus untuk mendapatkan perbaikan agar peningkatan kualitas kemandirian anak terus berlanjut dan meningkat.

Ketiga, peran stakeholder dalam pembinaan anak menjadi sangat penting, karenanya perlu upaya yang serius dan terencana agar pemerintah (RPSPA), guru kelas, orang tua dan pekerja sosial bisa meningkatkan kapasitas dan perannya untuk kemajuan pembinaan kemandirian anak.

\section{DAFTAR PUSTAKA}

Borg, W.R \& Gall, M.D. (1979). Educational research: An introduction. New York: Southend Press.

Gunarsa, Y.S \& Gunarsa D.S. (1991). Psikologi untuk membimbing. Jakarta: PT. BPK Gunung Mulia.

Irawati, R. (2011). Training 1: The role of trainer/ instructor. Akses: 15 Juni 2011. Alamat: http:// blog.stie-mce.ac.id/rina/2011/04/27/seluk-beluktentang-tenaga-pelatih-trai nerinstructor/.

Linton, R. (1984). Antropologi: Suatu penyelidikan tentang manusia (The study of man). (Penterjemah Firmansyah). Bandung: Jemmars

Moekijat. (1990). Evaluasi pelatihan dalam rangka meningkatkan produktivitas perusahaan.
Bandung: Mandar Maju

Soetarso. (1980). Kesejahteraan sosial, pelayanan sosial, dan kebijaksanaan sosial. Bandung: STKS

Sumantri, S. (2000). Pelatihan dan pengembangan sumber daya manusia. Bandung: Fakultas Psikologi Unpad

Syaodih, N. (1993). Pengembangan kemandirian: Suatu tinjauan kurikuler psikologis. Pidato Pengukuhan Guru Besar Pada IKIP Bandung: Tidak diterbitkan.

Undang-Undang Sistem Pendidikan Nasional No. 20 Tahun 2003 